\title{
Desain Rute Jaringan Moda Bus Kota Sebagai Antisipasi Kemacetan di Kota Balikpapan
}

\author{
Winarni $^{1}$, Evina Rahmatya Pratiwi', Subchan ${ }^{3}$ \\ 1,2 Program Studi Matematika, Institut Teknologi Kalimantan, Balikpapan. Email: winarni@itk.ac.id \\ ${ }^{3}$ Jurusan Matematika, Institut Teknologi Sepulu Nopember, Surabaya. Email: subchan@matematika.its.ac.id
}

\begin{abstract}
Public transport facilities are fundamental needs as population growth and society mobility increases. Nowadays, Balikpapan is one of the cities growing quite rapidly, including the level of society mobility. If it is not anticipated, this could lead Balikpapan becomes a crowded city such as Jakarta, Surabaya, Bandung and others. One of public transportation in Balikpapan is angkot which has capacity only about 10 passengers. Others are taxi and online transportation such as Gojek, Go-Car, and Grab. These are not yet the appropriate solution for public transportation services for all levels of society. Thus, it needs to be developed the integrated mass public transportation system in Balikpapan and become an alternative solution to the problems. One of the public demands in using public transportation service is passengers can reach any location from anywhere (strongly connected). Therefore, it is necessary to design the route of mass public transport system such as city busway, that is Trans Balikpapan Busway. This research use graph concept to design Trans Balikpapan Busway route. The result is the design of Trans Balikpapan Busway route with eight coridors. It is ilustrated by a directed graph. The matrix which represents the graph has unique eigen value, consequently the graph is strongly connected. It means Trans Balikpapan Busway network connects all districts in Balikpapan with places whenever people ussually visit such as schools, campuses, shops, malls, hospitals, terminals, air port, harbours, institutions, companies, recreation destinations, etc.
\end{abstract}

Keywords: graph, route, strongly connected, Trans Balikpapan

\begin{abstract}
Abstrak
Fasilitas transportasi umum merupakan kebutuhan vital seiring pertumbuhan penduduk dan mobilitas masyarakat meningkat. Saat ini, Balikpapan adalah salah satu kota yang berkembang cukup pesat, termasuk tingkat mobilitas masyarakat. Jika tidak diantisipasi, ini dapat menyebabkan Balikpapan menjadi kota yang padat seperti Jakarta, Surabaya, Bandung dan lain-lain. Salah satu angkutan umum di Balikpapan adalah angkutan kota yang kapasitasnya hanya sekitar 10 penumpang. Angkutan umum lainnya adalah taksi argo dan transportasi online seperti Gojek, Go-Car, dan Grab. Solusi tersebut belum tepat untuk layanan transportasi umum bagi semua lapisan masyakat. Oleh karena itu, perlu dikembangkan sistem transportasi umum massal terpadu di Balikpapan dan menjadi solusi alternatif untuk masalah tersebut. Salah satu tuntutan masyarakat dalam menggunakan layanan angkutan umum adalah penumpang dapat mencapai suatu lokasi dari mana saja (strongly connected). Oleh sebab itu, perlu dirancang rute sistem transportasi umum massal seperti moda bus kota yang dinamakan Trans Balikpapan Busway. Pada paper ini, digunakan konsep graf untuk merancang rute Trans Balikpapan Busway. Hasil penelitian ini adalah desain rute Trans Balikpapan Busway. Jaringan Trans Balikpapan Busway diilustrasikan dalam graf berarah. Matriks yang mewakili graf tersebut memiliki nilai eigen yang tunggal atau unik, karena itu dapat disimpulkan graf tersebut strongly connected. Hal ini berarti jaringan Trans Balikpapan Busway menghubungkan semua kecamatan di Balikpapan beserta tempat-tempat yang biasa dikunjungi oleh masyarakat seperti sekolah/kampus, pasar, mall, rumah sakit, terminal, bandara, pelabuhan, instansi, perusahaan, tujuan rekreasi dan lain-lain.
\end{abstract}

Kata kunci:, graf, rute, strongly connected, Trans Balikpapan

\section{Pendahuluan}

Dewasa ini kota Balikpapan berkembang cukup pesat, baik pembangunan insfrastruktur, gedunggedung, perusahaan, jumlah penduduk, jumlah pendatang, jumlah kendaraan bermotor yang beredar di jalan raya setiap hari khususnya kendaraan pribadi. Jika hal ini tidak diantisipasi maka suatu saat Balikpapan bisa menjadi kota macet seperti kota Jakarta atau Surabaya. 
Kota Balikapapan adalah salah satu kota besar di Indonesia. Meski bukan ibu kota propinsi tetapi aktivitas mobilitas manusia dan barang di kota ini cukup tinggi. Jumlah penduduk Kota Balikpapan berdasarkan proyeksi penduduk tahun 2016 sebanyak 625.968 jiwa (BPS Kota Balikpapan, 2017). Proyeksi jumlah penduduk Kota Balikpapan tahun 2017 sebanyak 636.012 jiwa, sedangkan pada tahun 2018, 2019, dan 2020 proyeksi jumlah penduduk Kota Balikpapan adalah 645.727, 655.178, dan 664.201 jiwa (BPS Kota Balikpapan, 2018). Hasil proyeksi tersebut berdasarkan data jumlah penduduk yang diperoleh dari Sensus Penduduk 2010 belum memperhitungkan jumlah migrasi.penduduk ke Kota Balikpapan.

Menurut Disdukcapil Balikpapan, sepanjang tahun 2015 terjadi migrasi ke Kota Balikpapan sebanyak 31.199 jiwa, hal ini melebih angka kelahiran yang hanya 12.199 jiwa. Sedangkan angka kematian tahun 2015 hanya 2.893 jiwa. Dari semua faktor tersebut yaitu kelahiran, kematian, dan migrasi, diperoleh angka pertumbuhan penduduk sebesar 4,22 persen pada tahun 2015 (Republika, 2016). Disdukcapil Balikpapan juga mendata 29.201 pendatang menetap di Balikpapan selama 2016. Sementara hingga Juni 2017, data menunjukkan 9.854 pendatang masuk Balikpapan dan menetap (Kompas, 2017). Menurut Kadisdukcapil Balikpapan, dalam sebulan jumlah pendatang di kota Balikpapan bisa mencapai 2.000 orang dan itupun pendatang yang membawa surat pindah resmi. Dalam setahun, jumlah pendatang bisa mencapai 25.000 orang (Tribunnews, 2018). Hal tersebut membuat jumlah penduduk di kota Balikpapan semakin padat.

Seiring meningkatnya pertumbuhan jumlah penduduk, kebutuhan meningkat sehingga menimbulkan peningkatan aktivitas kota. Peningkatan tersebut menimbulkan perpindahan orang maupun barang yang disebut dengan transportasi (Alhadar, 2011). Menurut Direktorat Jenderal Lalu Lintas Polda Kaltim, jumlah kendaraan di Balikpapan mengalami peningkatan rata-rata sebesar 6,8\% dari tahun 2012 sampai 2015 (BPS Kaltim, 2016). Tahun 2016 jumlah kendaraan di Balikpapan adalah 553.619 (BPS Kota Balikpapan, 2017). Sedangkan pada tahun 2017 jumlah kendaraan di Balikpapan sebanyak 572.976 kendaraan (BPS Kota Balikpapan, 2018).

Seiring makin bertambahnya tingkat mobilitas masyarakat baik penduduk, pendatang maupun sekedar singgah di kota Balikpapan, tentu fasilitas transportasi umum merupakan salah satu sarana penting yang dibutuhkan oleh masyarakat. Layanan transportasi umum kota Balikpapan sampai saat ini masih dilayani oleh angkutan kota (angkot) dengan tujuh trayek yang masih beroperasi yaitu trayek 1, 2a, 3, 5, 6, 7 dan 8. Adapun trayek 2 dan 4 sudah tidak beroperasi lagi. Daya angkut satu angkutan kota hanya antara 10 - 12 penumpang sudah tidak sesuai lagi untuk saat ini digunakan pada koridor jalan utama/poros. Perlu adanya moda transportasi dengan daya angkut lebih banyak dengan layanan yang lebih baik.

Hasil perhitungan kinerja angkutan kota berdasarkan ketersediaan angkutan bernilai kurang karena memiliki ketersediaan di bawah standar yaitu hanya $4 \%$ sampai $22,6 \%$ di mana hal tersebut kurang dari $80 \%$. Load faktor untuk trayek nomor 8 memiliki kinerja yang buruk dengan nilai $98 \%$ pada waktu peak hours menimbulkan ketidaknyamanan penumpang karena melebihi standar yakni $80 \%$. Dilihat dari variabel prasarana juga masih dinilai rendah. Selain itu, terdapat overlap 3 trayek khususnya di Jalan Letjen Suprapto yang dinilai melebihi batas maksimal overlap (Fajarini, 2018). Terkait dengan penyelenggaraan angkutan umum, Menteri Perhubungan menegaskan perlunya dilakukan pengembangan Sistem Angkutan Umum Massal (SAUM) dengan prinsip penyelenggaraan angkutan umum massal "Safe, Fastest, Cheap, Biggest" yang dapat dijadikan acuan dalam pelaksanaan penataan lalu lintas yang efisien sehingga dapat terwujud kondisi lalu lintas yang lancar dan terkendali (Departemen Perhubungan RI, 2011). Pemerintah bisa berkaca pada kota-kota di negara-negara yang sudah menerapkan sistem transportasi massal yang terintegrasi dengan baik. Ketersediaan transportasi umum yang memadai adalah salah satu wujud layanan pemerintah kepada masyarakat bukan untuk tujuan komersial semata. Hal ini harus menjadi perencanaan tata kota (Winarni, 2017).

Layanan transportasi massal yang masih belum bisa memenuhi kebutuhan masyarakat menjadi peluang maraknya bisnis jasa transportasi online di Jakarta dan berkembang ke kota-kota besar lain di Indonesia termasuk Balikpapan. Tetapi, akhirnya juga membawa polemik antara pengelola taxi resmi dengan jasa taxi online, antara jasa ojek konvensional dengan ojek online. Di satu sisi munculnya layanan jasa transportasi online memberi solusi atas kebutuhan transportasi bagi masyarakat, tetapi di sisi lain hal ini 
tidak memberikan solusi masalah kemacetan, justru berpotensi menambah kemacetan Layanan jasa transportasi online juga berpotensi menimbulkan masalah energi, polusi udara, krimilitas. Jadi, pengembangan layanan Sistem Angkutan Umum Massal (SAUM) merupakan kebutuhan mutlak yang harus dipikirkan bersama, khususnya oleh pemerintah. Oleh karena itu, dalam penelitian ini disusun desain rute jaringan moda bus kota Balikpapan, yang selanjutnya dinamakan Trans Balikpapan Busway. Jaringan tersebut menghubungkan semua kecamatan di Balikpapan beserta tempat-tempat yang biasa menjadi tujuan masyarakat dan keramaian massa seperti sekolah/kampus, pasar, mall, rumah sakit, terminal, bandara, pelabuhan, instansi, perusahaan, tujuan rekreasi dan lain-lain.

\section{Metode}

Adapun metode penelitian yang dilakukan dalam penelitian ini sebagai berikut:

2.1 Studi pustaka dan pengumpulan data terkait sistem angkutan umum di Balikpapan. Tahap ini diawali dengan mengumpulkan informasi mengenai sistem angkutan umum di Balikpapan dan masalah atau keluhan masyarakat terkait dengan layanan transportasi umum di Balikpapan. Informasi dikumpulkan dari beberapa sumber, yaitu website yang terkait dengan informasi mengenai transportasi umum, Departemen Perhubungan Kota Balikpapan, dan observasi langsung dan survey di lapangan.

2.2 Berdasarkan data yang diperoleh di tahap (i), selanjutnya akan disusun peta rute dan graph dari jaringan busway Trans Balikpapan, di mana node-nodenya adalah halte-halte transfer dan haltehalte ujung koridor sedangkan arc-nya mempunyai bobot waktu tempuh antar node tersebut. Adapun data waktu tempuh masing-masing rute yang diobservasi selama beberapa hari khususnya waktu peak hour.

\section{Hasil dan Pembahasan}

Berdasarkan hasil pengumpulan informasi dan data mengenai sistem angkutan umum di kota Balikpapan baik dari Dinas Perhubungan Kota Balikpapan, website, observasi langsung dan informasi keluhan masyarakat yang terkait dengan pelayanan transportasi umum di Balikpapan, dalam penelitian ini didesain peta jaringan rute moda bus kota TransBalikpapan. Selanjutnya peta jaringan rute moda bus kota tersebut disusun menjadi sebuah jaringan graf berbobot. Jaringan rute moda bus kota Trans Balikpapanyang disusun dalam penelitian ini terdiri dari 8 koridor. Setiap koridor memiliki terminal sebagai tempat awal keberangkatan dan keberangkat dan tempat pemberhentian akhir. Delapan koridon tersebut adalah:

1. Koridor A (Kampung Baru menuju Terminal Damai, melalui Jalan Yos Sudarso),

2. Koridor B (Terminal Damai menuju Penangkaran Buaya),

3. Koridor C (Terminal Damai menuju Terminal Batu Ampar),

4. Koridor D (Bandara menuju Terminal Batu Ampar),

5. Koridor E (Terminal Batu Ampar menuju Pelabuhan Kariangau),

6. Koridor F (Terminal Batu Ampar menuju Batas Kota Balikpapan KM. 24),

7. Koridor G (Kampung Baru menuju Terminal Damai, melalui Jalan Jenderal Achmad Yani),

8. Koridor H (Kampus Baru menuju Terminal Batu Ampar).

Denah jaringan Trans Balikpapan Busway digambarkan dalam bentuk graf berbobot, dengan node pada graf merepresentasikan terminal yang berada pada ujung dan pangkal masing-masing koridor. Bobot pada arc graf merupakan representasi dari waktu tempuh antar terminal ttersebut. Data waktu tempuh yang digunakan pada penelitian ini diperoleh dengan menggunakan bantuan google maps dan survey lapangan khususnya pada waktu-waktu sibuk atau peak hours. Faktor yang digunakan sebagai bahan pertimbangan dalam menetapkan jaringan trayek adalah pola tata guna tanah, pergerakan penumpang angkutan umum, kepadatan penduduk, daerah pelayanan, dan karakteristik jaringan (Departemen Perhubungan RI, 2002).

Berdasarkan hal itu dalam penelitian ini penentuan rute Trans BalikpapanBusway ditentukan berdasarkan batas-batas kota Balikpapan, pergerakan penduduk, kepadatan penduduk, daerah pelayanan 
yang tentunya mempertimbangkan tempat-tempat yang biasa dikunjungi oleh masyarakat seperti sekolah/kampus, perumahan, pasar, mall, rumah sakit, terminal, bandara, pelabuhan, instansi, perusahaan, tujuan wisata dan lain-lain, serta keberadaan terminal yang sudah ada di Balikpapan sehingga tidak perlu membangun semua terminal baru dari awal. Hal mendasar adalah jaringan rute yang disusun dipastikan strongly connected artinya dapat menjangkau seluruh wilayah kecamatan di Kota Balikpapan dan lokasi-lokasi yang biasa dikunjungi masyarakat. Selain itu, trayek yang disusun tidak tumpang tindih. Desain peta jaringan busway Trans Balikpapan yang dihasilkan dalam penelitian ini disajikan dalam bentuk peta pada Gambar 3.1 dan dalam bentuk graf berarah pada Gambar 3.2.

Graph berarah $G$ didefinisikan sebagai pasangan ( $V$, E), di mana $V$ adalah himpunan verteks (nodes) dan $\mathrm{E}$ adalah himpunan pasangan berurutan 2 verteks yang disebut dengan edges (arcs). Berurutan yang dimaksudkan adalah bahwa arc $(j, i)$ tidak sama dengan $(i, j)$. Hal inilah yang membedakan graph berarah dengan dengan graph (tak berarah). Didefinisikan banyaknya node adalah $n$, dan masing-masing node dilabeli dengan $1,2, \ldots, n$. Jika $(i, j) \in \mathrm{E}$, maka $i$ disebut node awal atau node asal dari $\operatorname{arc}(i, j)$ dan $j$ adalah node akhir atau node tujuan dari arc $(i, j)$. Secara grafik, node digambarkan dengan titik dan arc $(i, j)$ digambarkan dengan garis berarah dari $i$ ke $j$ (Baccelli F., dkk, 1992).

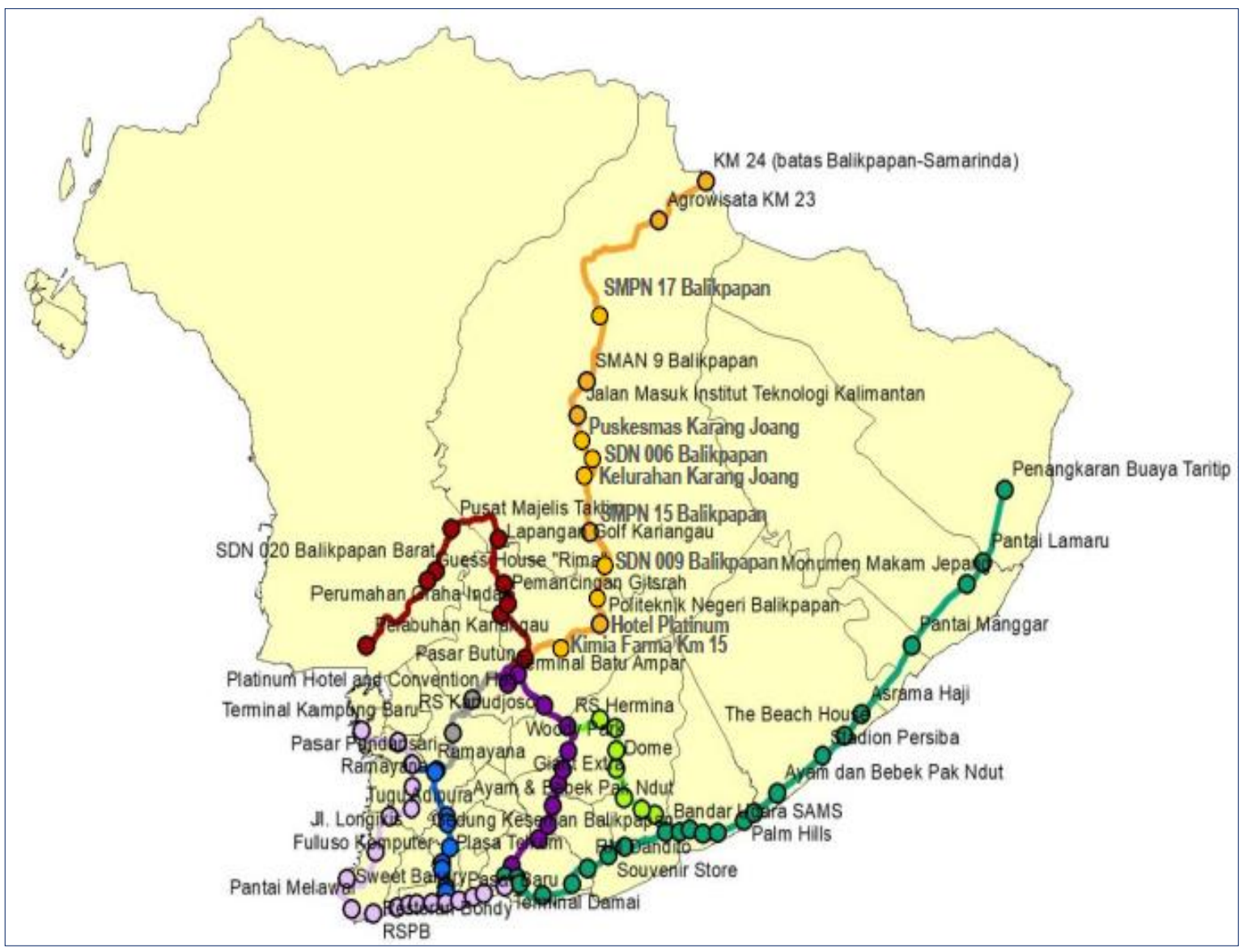

Gambar 3.1 Peta Rute Jaringan Trans BalikpapanBusway

Definisi 3.1 Precedence Graph (Bacelli dkk., 1992).

Precedence graph dari matriks bujur sangkar $A$ dengan elemennya $a_{i j}$ adalah sebuah digraph berbobot dengan node $n$ dan sebuah arc $(j, i)$ jika $a_{i j} \neq \varepsilon$, dimana bobot pada arc ini adalah nilai dari $a_{i j}$. Precedence graph dinotasikan $G(A)$.

Suatu graph $G=(V, \mathrm{E})$ dikatakan terhubung dengan kuat atau strong connected jika hanya jika untuk setiap dua node $i$ dan $j \in V$, terdapat suatu lintasan dari node $i$ ke node $j$ atau dengan kata lain node $j$ dapat diraih (reachable) dari node $i$. Matriks $A \in \mathrm{R}_{\text {maks }}^{n \times n}$ disebut tak-tereduksi (irreducible) jika graph 
terhubung dari $A$ yaitu $G(A)$ strongly connected (Heidergott, B., dkk, 2006). Jika matriks $A$ tak-tereduksi maka dalam aljabar max-plus $A$ mempunyai eigenvalue tunggal (Subiono, 2000). Max-plus eigen value dan eigen vektor yang bersesuaian ada jika matriks A $A \in \mathrm{R}_{\text {maks }}^{n \times n}$ tak-tereduksi (Subiono, 2018)

Teorema 3.2 (Heidergott dkk., 2006). Sebarang matriks irreducible $A \in \mathrm{R}_{\text {maks }}^{n \times n}$ (A adalah matriks taktereduksi atau dengan kata lain $\mathcal{G}(A)$ adalah strongly connected) mempunyai satu dan hanya satu eigenvalue. Eigenvalue tersebut dinotasikan dengan $\lambda(A)$ adalah berhingga dan nilainya sama dengan bobot rata-rata maksimum dari circuit pada $G(A)$ yaitu:

$$
\lambda(A)=\operatorname{maks}_{p \in C(A)} \frac{|p|_{w}}{|p|_{l}}
$$

di mana $C(A)$ adalah himpunan semua circuit sederhana dalam $\mathcal{G}(A)$.

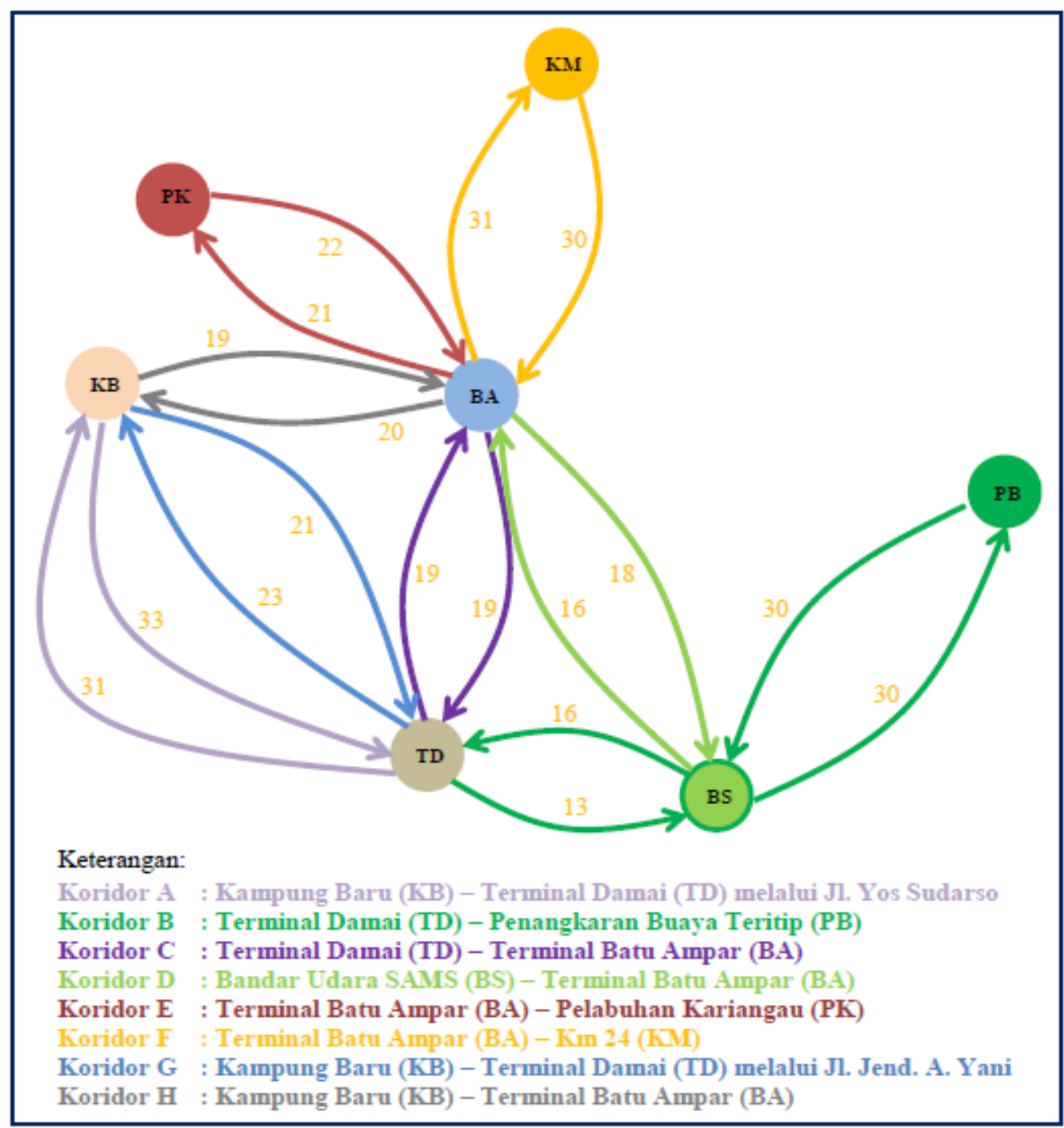

Gambar 3.2 Graf Jaringan Trans Balikpapan Busway

Berdasarkan graf jaringan Trans Balikpapan pada Gambar 3.2 di atas, dapat disusun suatu matriks yang merupakan representasi dari graf tersebut. Dalam hal ini, matriks tersebut adalah matriks $\boldsymbol{A}$ yaitu sebagai berikut: 


$$
A=\left(\begin{array}{ccccccccc}
\varepsilon & \varepsilon & 33 & \varepsilon & \varepsilon & \varepsilon & 19 & \varepsilon & \varepsilon \\
\varepsilon & \varepsilon & \varepsilon & 21 & \varepsilon & \varepsilon & 19 & \varepsilon & \varepsilon \\
31 & \varepsilon & \varepsilon & \varepsilon & 13 & \varepsilon & 19 & \varepsilon & \varepsilon \\
\varepsilon & 23 & \varepsilon & \varepsilon & 13 & \varepsilon & 19 & \varepsilon & \varepsilon \\
\varepsilon & \varepsilon & 16 & 16 & \varepsilon & 30 & 16 & \varepsilon & \varepsilon \\
\varepsilon & \varepsilon & \varepsilon & \varepsilon & 30 & \varepsilon & \varepsilon & \varepsilon & \varepsilon \\
20 & 20 & 19 & 19 & 18 & \varepsilon & \varepsilon & 21 & 31 \\
\varepsilon & \varepsilon & \varepsilon & \varepsilon & \varepsilon & \varepsilon & 22 & \varepsilon & \varepsilon \\
\varepsilon & \varepsilon & \varepsilon & \varepsilon & \varepsilon & \varepsilon & 30 & \varepsilon & \varepsilon
\end{array}\right)
$$

Dengan menggunakan software Scilab dengan Max-Plus Algebra Toolbox (Subiono, 2008) diperoleh nilai eigen matriks $A$ tersebut tunggal yaitu 32. Berdasarkan Teorema 3.2 disimpulkan bahwa $\mathcal{G}(A)$ strongly connected. Hal ini menunjukkan bahwa desain jaringan rute moda bus kota Trans Balikpapan strongly connected. Keberadaan jaringan rute yang strongly connected penting peranannya dalam penyusunan desain jadwalan keberangkatan armada di jaringan tersebut yang tersinkronisasi.

Selanjutnya karena jaringan graf tersebut sudah dipastikan strongly connected, dapat dimodelkan desain penjadwalan keberangkatan bus dalam jaringan tersebut dengan model aljabar max plus, seperti dalam penelitian sebelumnya antara lain paper yang ditulis oleh Winarni (2011) dan Fahim dkk. (2013). Saat ini, hal ini dapat dilakukan dengan menerapkan algoritma yang telah disusun oleh Subiono dkk. (2018) untuk mengkonstruksi jadwal reguler dari suatu jaringan transportasi umum. Desain penjadwalan jaringan moda bus di Balikpapan ini akan dipublikasikan dalam publikasi lainnya.

\section{Kesimpulan}

Hasil penelitian ini adalah desain rute Trans Balikpapan Busway yang strongly connected. Jaringan tersebut menghubungkan semua kecamatan di Balikpapan beserta tempat-tempat yang biasa menjadi tujuan masyarakat dan keramaian massa seperti sekolah/kampus, pasar, mall, rumah sakit, terminal, bandara, pelabuhan, instansi, perusahaan, tujuan rekreasi dan lain-lain. Matriks yang merepresentasikan jaringan tersebut memiliki nilai eigen tunggal dan terdapat aturan sinkronisasi yang menjamin bahwa penumpang dari sembarang titik dapat menuju sembarang titik lainnya.

\section{Ucapan Terima Kasih}

Penelitian ini didanai Kementerian Riset, Teknologo dan Pendidikan Tinggi (Kemristekdikti) Republik Indonesi melalui skema hibah Penelitian Dosen Pemula (PDP) Tahun 2018 dan atas kerjasama Dinas Perhubungan Kota Balikpapa dan LPPM Institut Teknologi Kalimantan. Oleh karena itu disampaikan terimakasih kepada Kemristekdikti, Dinas Perhubungan Kota Balikpapan, dan LPPM Institut Teknologi Kalimantan.

\section{Daftar Pustaka}

Alhadar, A. (2011). "Analisis Kinerja Jalan dalam Upaya Mengatasi Kemacetan Lalu Lintas pada Ruas Simpang Bersinyal di Kota Palu". SMARTek, Vol. 9, No. 4, hal. 327-366.

Baccelli, F. Cohen, G., Olsder, G. J., dan Quadrat, J. P., (1992), Synchronisation and Linearity, Algebra for Discrete Event System. John Wiley and Sons, Inc., New York.

BPS Kaltim. (2016). Banyaknya Kendaraan Bermotor Menurut Kabupaten/Kota (Unit), Tahun 2012 - 2015 [Online] tersedia di https://kaltim.bps.go.id/statictable/2015/03/11/136/banyaknya-kendaraan-bermotormenurut-kabupaten-kota-unit-tahun-2012-2015-.html diakses pada 28 September 2017.

BPS Kaltim. (2017). Proyeksi Penduduk Provinsi Kalimantan Timur Menurut Kabupaten/Kota (Perempuan+Laki-Laki) 2010-2020. [Online] tersedia di: https://kaltim.bps.go.id/dynamictable/2017/07/07/49/proyeksi-penduduk-provinsi-kalimantan-timurmenurut-kabupaten-kota-perempuan-laki-laki-2010-2020.html diakses pada 28 September 2017.

BPS Kota Balikpapan. (2017). Kota Balikpapan dalam Angka 2017. Badan Pusat Statistik Kota Balikpapan. Balikpapan. [Online] bisa diakses di: https://balikpapankota.bps.go.id/publication/2017/08/11/ed2877ad4ccd26d8fb7cdf44/kota-balikpapandalam-angka-2017.html diakses pada 28 September 2017.

BPS Kota Balikpapan. (2018). Kota Balikpapan dalam Angka 2018. Balikpapan. Badan Pusat Statistik Kota Balikpapan. [Online] bisa diakses di: 
https://balikpapankota.bps.go.id/publication/2018/08/16/8df63ffd73378cb97b4fc3eb/kota-balikpapandalam-angka-2018.html diakses pada 10 September 2018.

Chartrand, Garry and Linda Lesniak. (2016). Graph and Digraphs. California: Pacific Graw.

Departemen Perhubungan RI Direktorat Jendaral Perhubungan Darat.(2002). SK Dirjen Nomor: 687/AJ.206/DRJD/2002 tentang Pedoman Teknis Penyelenggaraan Angkutan Penumpang Umum Di Wilayah Perkotaan Dalam Trayek Tetap dan Teratur. [Online] tersedia di: http://hubdat.dephub.go.id/keputusan-dirjen/tahun-2002/423-sk-dirjen-no-687aj diakses pada 10 September 2017.

Departemen Perhubungan RI Direktorat Jendaral Perhubungan Darat. (2011). Peningkatan Pelayanan Publik Jadi Isu Utama Rakornis Hubdat 2011 [Online] tersedia di: http://dephub.go.id/beta2017/post/read/peningkatanpelayanan-publik-jadi-isu-utama-rakornis-hubdat-2011-6280 diakses pada tanggal 12 April 2017.

Fahim, K. Subchan, Subiono. (2013). “Aplikasi Aljabar Max-Plus Pada Pemodelan dan Penjadwalan Busway yang Diintegrasikan dengan Kereta Api Komuter”. JURNAL TEKNIK POMITS Vol. 1, No. 1, hal 1-6.

Fajarini, D. P. N. (2018). Evaluasi Kinerja Angkutan Kota Berdasarkan Kuantitas dan Kualitas Pelayanan Angkutan Kota di Balikpapan. Tugas Akhir. Institut Teknologi Kalimantan. Balikpapan.

Heidergott, B., Olsder G. J., danWoude, J. V. D., (2006), Max Plus at Work Modelling and Analysis of Synchronisation System: A Course on Max-Plus Algebra and Its Application, Priceton University Press, New Jersey.

Kompas. (2017). Pendatang yang Tak Miliki KTP Terancam Dipulangkan dari Balikpapan. [online] tersedia di: https://regional.kompas.com/read/2017/07/06/21023331/pendatang.yang.tak.miliki.ktp.terancam.dipulang kan.dari.balikpapan diakses pada 10 September 2018.

Republika. (2016). Jumlah Migran Dominasi Balikpapan. [Online] tersedia di: https://www.republika.co.id/berita/nasional/daerah/16/01/04/o0eivm346-jumlah-migran-dominasibalikpapan diakses pada 10 September 2018.

Tribunnews. (2018). Kadisdukcapil Balikpapan Sebut Pendatang di Balikpapan Bisa Mencapai 25000 Orang Tiap Tahun. [Online] tersedia di:http://kaltim.tribunnews.com/2018/08/30/kadisdukcapil-balikpapansebut-pendatang-di-balikpapan-bisa-mencapai-25000-orang-tiap-tahun diakses pada 10 September 2018.

Subiono. (2000). On Classes of Min-Max-Plus System and Their Application, Thesis, Technische Universiteit Delft, Delft.

Subiono dan Dieky, A. (2008). Max-plus Algebra Toolbox. http://www.scilab.org

Subiono. (2018). "Generalized Public Ttransportation Scheduling Using Max-Plus Algebra”. KYBERNETIKA Vol. 54, No.2, hal 243 - 267. DOI: 10.14736/kyb-2018-2-0243

Winarni. (2011), "Penjadwalan Jalur Bus Dalam Kota dengan Model Petrinet dan Aljabar Max-Plus", Jurnal CAUCHY, Vol. 1 No. 4. DOI: 10.18860/ca.v1i4.1796

Winarni. (2017). Sistem Transportasi Massal, Kebutuhan Mutlak. Kaltimpost, hal. 25 [Online] tersedia di http://kaltim.prokal.co/read/news/298347-sistem-transportasi-massal-kebutuhan-mutlak.html diakses pada tangaal 26 September 2018. 
Desain Rute Jaringan Moda Bus Kota sebagai Antisipasi Kemacetan di Kota Balikpapan

\section{Halaman sengaja dikosongkan}

